\title{
Smoke-enhanced seed germination in Mediterranean Lamiaceae
}

\author{
Şükrü Serter Çatav ${ }^{1}$, Köksal Küçükakyüz1, Kenan Akbaş ${ }^{1}$ and Çağatay Tavşanoğlu ${ }^{2 *}$ \\ ${ }^{1}$ Department of Biology, Mugla Sitki Koçman University, Kötekli 48000, Mugla, Turkey; ${ }^{2}$ Fire Ecology and \\ Seed Research Lab., Division of Ecology, Department of Biology, Hacettepe University, Beytepe 06800, Ankara, \\ Turkey
}

(Received 22 August 2013; accepted after revision 11 April 2014; first published online 22 May 2014)

\begin{abstract}
The role of smoke in fire-stimulated germination in the Mediterranean Basin has often been underestimated. A few records on smoke-enhanced germination are present in Mediterranean Lamiaceae species, but there is still a shortage of information to allow generalizations about this family to be made. To test the hypothesis that smoke enhances germination in Mediterranean Lamiaceae species, we performed a germination experiment, including aqueous smoke treatments in various concentrations (1:1, 1:10 and 1:100) on seven eastern Mediterranean Lamiaceae taxa. Six of the studied taxa (Lavandula stoechas, Origanum onites, Phlomis bourgaei, Stachys cretica ssp. smyrnaea, Satureja thymbra, Teucrium lamiifolium ssp. stachyophyllum) showed significant increments in germination percentage in at least one smoke treatment, as compared to the control. Moreover, L. stoechas, S. thymbra and T. lamiifolium ssp. stachyophyllum displayed faster germination in at least one smoke treatment than in the control. Of the species showing significant increments in germination percentages after aqueous smoke application, at least one single concentration of smoke solution did not stimulate germination, except in L. stoechas and S. thymbra which responded positively to all smoke treatments. Therefore, the concentration of aqueous smoke that improved germination was speciesspecific. Our results contribute to the current limited knowledge on smoke-enhanced germination in Mediterranean Lamiaceae, and support the idea that smoke is an important germination cue for this family.
\end{abstract}

Keywords: fire, germination, Lamiaceae, Mediterranean Basin, smoke

*Correspondence

Fax: + 903122992028

Email: ctavsan@hacettepe.edu.tr

\section{Introduction}

Plant community dynamics in many ecosystems are largely shaped by wildfires (Brown and Smith, 2000; Bond and Keeley, 2005). Many plants are able to regenerate by mechanisms such as resprouting and seeding after fires, especially in Mediterranean-type ecosystems (Keeley and Zedler, 1978; Pausas and Verdú, 2005). Post-fire regeneration by seeds is driven by fire-induced seed release or germination in Mediterranean plant species (Keeley et al., 2012). The important role of fire-related cues (heat and smoke) in the stimulation of germination in many plants is well known. Heat-stimulated germination, which is a common property among hard-seeded plants, has been shown in fire-prone Mediterranean-type ecosystems (Thanos et al., 1992; Keeley and Bond, 1997; Herranz et al., 1998; Moreira et al., 2010). Smokestimulated germination has also been demonstrated in a wide range of species from both fire-prone (Brown, 1993a; Dixon et al., 1995; Keeley and Bond, 1997; Keeley and Fotheringham, 1998; Moreira et al., 2010) and nonfire-prone areas (Pierce et al., 1995; Adkins and Peters, 2001; Daws et al., 2007) of the world.

Lamiaceae is a plant family containing over 240 genera and 6500 species worldwide. Although the family has a worldwide distribution, it shows great diversity in the Mediterranean Basin, Irano-Turanian floristic region and eastern Asia (Takhtajan, 2009), and is represented by many endemic taxa in local floras of this region (e.g. Yeşilyurt and Akaydın, 2012). Many members of the family are of economic importance, including medicinal plants, culinary herbs, fragrance plants and ornamentals (Simpson, 2010). In particular, species of Lavandula (lavender), Mentha (mint), Melissa (lemon balm), Ocimum (basil), Origanum (oregano), Rosmarinus (rosemary), Salvia (sage), Satureja (savory) and Thymus (thyme) are widely used as culinary herbs by local people of circum-Mediterranean areas (Naghibi et al., 2005; Gürdal and Kültür, 2013) and in North America (Small, 2006). At the same time, Lamiaceae taxa are of ecological importance in plant 
communities of the Mediterranean area, and can be found in various Mediterranean habitats, such as maquis and phyrgana, where fire plays a key role in shaping the structure of plant communities (Verdú and Pausas, 2007; Keeley et al., 2012). Species of Lamiaceae are also found frequently in burned Mediterranean habitats (Kazanis and Arianoutsou, 2004; Kavgaci et al., 2010; Tavşanoğlu and Gürkan, 2014) on account of seedling emergence after fire (Paula et al., 2009). This can be attributed to their enhanced germination ability after fires (Moreira et al., 2010). Indeed, Lamiaceae is one of the main families found in the Northern Hemisphere with numerous species showing smokestimulated germination (Keeley et al., 2012).

Although there are records of smoke-stimulated germination in Lamiaceae taxa worldwide, many of these come from outside of the Mediterranean-type ecosystems (Clarke et al., 2000; Tang et al., 2003; Pennacchio et al., 2005; Tierney, 2006; Todorović et al., 2007; Ervin et al., 2010; Schwilk and Zavala, 2012; Tavşanoğlu et al., in prep.). This suggests that the possibly significant role of smoke in the recovery of Lamiaceae species in fire-driven Mediterranean ecosystems might have been overlooked (but see Keeley and Fotheringham, 1998; Moreira et al., 2010). In the Mediterranean Basin, in particular, few studies have tested the germination response of Lamiaceae species to smoke (Crosti et al., 2006; Reyes and Trabaud, 2009; Moreira et al., 2010; Çatav et al., 2012). As a consequence, there is still a shortage of information on the role of smoke in post-fire germination of the members of the Lamiaceae family.

Based on the records of smoke-stimulated germination in many species belonging to the Lamiaceae worldwide, we hypothesized that smoke will enhance germination of Mediterranean Lamiaceae species. To test this hypothesis, we performed a germination experiment with seeds of seven Lamiaceae taxa growing in natural Mediterranean habitats. The percentage and rate of germination of each taxon were assessed in aqueous smoke treatments at different concentrations, and these results were compared to the controls to determine if smoke treatments resulted in any increment in germination percentage and rate in the studied taxa. By conducting this experiment, we aimed to clarify the role of smoke in enhanced germination of Mediterranean Lamiaceae species.

\section{Materials and methods}

\section{Study taxa, study area and seed collection}

We collected the seeds of seven Lamiaceae taxa growing in natural habitats of Muğla province, south-western Turkey, the eastern Mediterranean Basin (Table 1). These taxa have a soil seed bank, have obligate or facultative seeder regeneration mode, and are found in post-fire environments in the study area (Tavşanoğlu and Gürkan, 2014). The study area has a Mediterranean climate with wet winters and dry summers. The collections were carried out between July and September 2012, coinciding with the propagule dispersal period of each taxon. Ripe nutlets (seeds) of each taxon were collected from a minimum of ten individuals of the same population, except Phlomis bourgaei in which fewer individuals could be found. Seeds were separated from the dry flower parts by hand and stored in paper envelopes under laboratory conditions until the start of the experiment in October 2012. For each taxon, mean seed mass was determined for four replicates of 100 seeds (three replicates in $P$. bourgaei due to the limited number of seeds).

\section{Preparation of aqueous smoke solutions}

Since the active compounds of smoke for germination are very stable in aqueous solutions (Van Staden et al., 2000) and aqueous extracts of smoke are equally as effective as airborne smoke in stimulating seed germination (Brown, 1993b; Dixon et al., 1995), we used aqueous smoke solutions as smoke treatment for the experiment. Dry needles of Pinus brutia, the pine

Table 1. List of the studied taxa. Growth form (GF), seed collection locality (Loc) and altitude (alt; $\mathrm{m}$ a.s.l), mean ( \pm SE) seed size (in $\mathrm{mg}$ ) and distributional range of the taxa are given. Nomenclature follows Davis (1965-1985)

\begin{tabular}{|c|c|c|c|c|c|}
\hline Taxa & GF & Loc & alt & Seed size & Range \\
\hline Lavandula stoechas L. & $\mathrm{w}$ & $36^{\circ} 53^{\prime} \mathrm{N}-28^{\circ} 11^{\prime} \mathrm{E}$ & 22 & $0.60 \pm 0.01$ & MB \\
\hline Origanum onites L. & $\mathrm{w}$ & $37^{\circ} 00^{\prime} \mathrm{N}-28^{\circ} 21^{\prime} \mathrm{E}$ & 65 & $0.06 \pm 0.00$ & EMB \\
\hline Phlomis bourgaei Boiss. & $\mathrm{w}$ & $37^{\circ} 09^{\prime} \mathrm{N}-28^{\circ} 22^{\prime} \mathrm{E}$ & 650 & $6.55 \pm 0.32$ & $\mathrm{EMB}(\mathrm{E})$ \\
\hline Satureja thymbra L. & $\mathrm{w}$ & $36^{\circ} 43^{\prime} \mathrm{N}-27^{\circ} 26^{\prime} \mathrm{E}$ & 273 & $0.56 \pm 0.02$ & EMB \\
\hline Stachys cretica L. ssp. smyrnaea Rech.Fil. & $\mathrm{p}$ & $37^{\circ} 09^{\prime} \mathrm{N}-28^{\circ} 22^{\prime} \mathrm{E}$ & 650 & $2.64 \pm 0.05$ & $\mathrm{EMB}(\mathrm{E})$ \\
\hline Teucrium divaricatum Sieber ssp. divaricatum & $\mathrm{W}$ & $36^{\circ} 43^{\prime} \mathrm{N}-27^{\circ} 27^{\prime} \mathrm{E}$ & 405 & $1.69 \pm 0.03$ & EMB \\
\hline Teucrium lamiifolium D’Urv. ssp. stachyophyllum (P.H. Davis) Hedge \& Ekim & $\mathrm{p}$ & $37^{\circ} 00^{\prime} \mathrm{N}-28^{\circ} 21^{\prime} \mathrm{E}$ & 65 & $0.63 \pm 0.02$ & EMB \\
\hline
\end{tabular}

w, woody; p, perennial herb; MB, the whole Mediterranean Basin; EMB, the eastern MB; E, regionally endemic to Turkey and the east Aegean islands. 
species dominating the vegetation in most of the study region, were separated into small pieces to use as the plant material needed for preparing aqueous smoke solutions. Four replicates of $5 \mathrm{~g}$ of this plant material were heated separately in metallic containers in the oven for $30 \mathrm{~min}$ at $193 \pm 1^{\circ} \mathrm{C}$ (Jäger et al., 1996; Moreira et al., 2010; Çatav et al., 2012). The mouth of each container was tightly covered by an aluminium slab to capture the smoke generated from the burnt plant material. After the treatment, $50 \mathrm{ml}$ of distilled water was added to the plant material in the container and was left for $10 \mathrm{~min}$ (Jäger et al., 1996). By this procedure, the active chemicals found in smoke dissolved in the water in the container. The solution was filtered into a bottle to obtain concentrated smoke solution (hereafter, smoke 1:1; pH 4.32). One millilitre of concentrated solution was diluted in 10 and $100 \mathrm{ml}$ of distilled water to prepare lower concentrations of smoke solutions (hereafter, smoke 1:10, $\mathrm{pH} 4.40$, and smoke 1:100, pH 5.03, respectively). Since previous observations revealed that smoke-stimulated germination was independent of the $\mathrm{pH}$ value (Brown and Van Staden, 1997), we did not adjust the $\mathrm{pH}$ of the different concentrations of smoke solutions and the control.

\section{Germination experiment}

Seeds of each taxon were incubated in different concentrations of smoke solution for $24 \mathrm{~h}$. A group of seeds from each taxon was also incubated in distilled water ( $\mathrm{pH}$ 5.75) for $24 \mathrm{~h}$ to be used as a control for the aqueous smoke treatments. After the treatments were applied, seeds were sown in Petri dishes containing agar $(0.7 \%)$ as substrate. Each treatment consisted of four replicates of 25 seeds. Petri dishes were placed in an incubator set at $20.0^{\circ} \mathrm{C}\left( \pm 0.5^{\circ} \mathrm{C}\right)$ in darkness, i.e. favourable conditions for the germination of many Mediterranean species (Thanos et al., 1991; Luna et al., 2012). The seeds were monitored for germination on a daily basis during the first $10 \mathrm{~d}$ of the incubation, and then weekly until the end of the experiment.
The criterion of germination was the observation of visible radicle protrusion. Germinated seeds were counted and removed from the Petri dishes at every check. The experiment was finalized after 7 weeks of incubation. The viability of non-germinated seeds was determined by the cut test, and the seeds with an intact embryo were classified as viable.

\section{Data analysis}

For each taxon we included the germinated versus non-germinated seeds (including intact but not empty ones) in the analysis. The probability of germination stimulation by each smoke treatment was determined using analysis of deviance (GLM) with binomial error distribution (Moreira et al., 2010). Mean germination time was calculated using the equation $\Sigma(n D) / \Sigma n$, where $n$ is the number of seeds germinated on day $D$ and $D$ is the number of days from the beginning of the incubation period (Tompsett and Pritchard, 1998). Dunnett's test was used for comparison of mean germination time for smoke treatments and the control in each taxon. Data normality and homoscedasticity were tested using the Shapiro-Wilk and Bartlett's tests before each analysis, respectively. Since the prerequisites for parametric tests were obtained in all cases, germination time data were not transformed before analysis.

\section{Results}

Of the seven taxa examined, six showed significant increments in germination percentage in at least one smoke solution compared to the control (Table 2). Among the studied taxa, Lavandula stoechas, Origanum onites and Teucrium lamiifolium ssp. stachyophyllum had relatively higher germination percentages $(>68 \%)$ in control conditions. On the other hand, Stachys cretica ssp. smyrnaea and Teucrium divaricatum ssp. divaricatum had very low germination percentages $(<3 \%)$ in

Table 2. Mean ( \pm SE) germination percentage in the control and after smoke treatments. The concentrations of different smoke treatments are shown as 1:1, 1:10 and 1:100. The significance of the pairwise comparison of each treatment with the corresponding control (GLM) is given (ns, not significant; $\left.{ }^{*} P<0.05 ;{ }^{* *} P<0.01 ;{ }^{* * *} P<0.001 ;{ }^{* * * *} P<0.0001\right)$

\begin{tabular}{lrrcc}
\hline & & \multicolumn{3}{c}{ Smoke treatment } \\
\cline { 3 - 5 } Taxa & Control & \multicolumn{1}{c}{$1: 1$} & $1: 10$ & $1: 100$ \\
\hline L. stoechas & $68.6 \pm 2.3$ & $88.9 \pm 5.2^{* * *}$ & $88.1 \pm 4.56^{* *}$ & $94.6 \pm 3.2^{* * * *}$ \\
O. onites & $83.1 \pm 4.7$ & $92.0 \pm 2.3^{\text {ns }}$ & $93.8 \pm 4.7^{*}$ & $97.0 \pm 1.8^{* *}$ \\
P. bourgaei & $21.4 \pm 3.6$ & $22.5 \pm 4.0^{\text {ns }}$ & $40.9 \pm 3.5^{*}$ & - \\
S. thymbra & $47.0 \pm 4.4$ & $86.5 \pm 5.6^{* * * *}$ & $67.3 \pm 12.2^{*}$ & $77.0 \pm 3.6^{* * *}$ \\
S. cretica ssp. smyrnaea & $0.0 \pm 0.0$ & $40.9 \pm 2.0^{* * * *}$ & $11.0 \pm 3.0^{* * * * *}$ & $1.0 \pm 1.0^{\text {ns }}$ \\
T. divaricatum ssp. divaricatum & $2.1 \pm 2.1$ & $2.0 \pm 1.1^{\text {ns }}$ & $1.0 \pm 1.0^{\text {ns }}$ & $1.0 \pm 1.0^{\text {ns }}$ \\
T. lamiifolium ssp. stachyophyllum & $75.5 \pm 3.4$ & $77.5 \pm 5.6^{\text {ns }}$ & $75.8 \pm 5.4^{\text {ns }}$ & $97.7 \pm 1.3^{* * * *}$ \\
\hline
\end{tabular}


Table 3. Mean ( \pm SE) germination time (in days) in the control and after smoke treatments. The concentrations of different smoke treatments are shown as 1:1, 1:10 and 1:100. The significance of the pairwise comparison of each treatment with the corresponding control (Dunnett's test) is given (ns, not significant; ${ }^{*} P<0.05$; ${ }^{* *} P<0.01$; ${ }^{* * *} P<0.001$ ). No statistical analysis was performed for T. divaricatum ssp. divaricatum and for $S$. cretica ssp. smyrnaea since very little and no germination was observed in the control, respectively.

\begin{tabular}{lcccc}
\hline & & \multicolumn{3}{c}{ Smoke treatment } \\
\cline { 3 - 5 } Taxa & Control & $1: 1$ & $1: 10$ & $1: 100$ \\
\hline L. stoechas & $8.0 \pm 0.8$ & $6.3 \pm 0.6^{\text {ns }}$ & $5.3 \pm 0.3^{* *}$ & $6.7 \pm 0.4^{\text {ns }}$ \\
O. onites & $4.3 \pm 0.2$ & $4.5 \pm 0.5^{\text {ns }}$ & $4.9 \pm 0.3^{\text {ns }}$ & $6.3 \pm 0.3^{* *}$ \\
P. bourgaei & $39.7 \pm 3.4$ & $37.6 \pm 1.5^{\text {ns }}$ & $39.4 \pm 1.2^{\text {ns }}$ & - \\
S. thymbra & $14.9 \pm 1.4$ & $7.8 \pm 1.7^{*}$ & $7.7 \pm 1.9^{*}$ & $8.7 \pm 1.0^{*}$ \\
S. cretica ssp. smyrnaea & - & $2.9 \pm 0.2$ & $3.4 \pm 0.6$ & - \\
T. lamiifolium ssp. stachyophyllum & $14.8 \pm 0.6$ & $16.8 \pm 1.2^{\text {ns }}$ & $16.7 \pm 0.9^{\text {ns }}$ & $7.6 \pm 0.4^{* * *}$ \\
\hline
\end{tabular}

control conditions, suggesting the presence of a high degree of dormancy in these taxa (Table 2). Application of any smoke solution did not break the dormancy in T. divaricatum ssp. divaricatum, but Stachys cretica ssp. smyrnaea responded positively. In the taxa showing significant increments in germination percentages after aqueous smoke application, at least one single concentration of smoke solution did not stimulate the germination, except in L. stoechas and Satureja thymbra which responded positively to all aqueous smoke treatments. On the other hand, none of the smoke concentrations significantly decreased the germination percentages (Table 2).

L. stoechas, S. thymbra and T. lamiifolium ssp. stachyophyllum had faster germination in at least one smoke solution than in the control (Table 3). No significant difference in germination rate was found between the control and aqueous smoke treatments in the other taxa tested, except $O$. onites which had a significantly slower germination rate in smoke 1:100 treatment (Table 3). No result of mean germination time was obtained for $T$. divaricatum $\mathrm{ssp}$. divaricatum for any treatment, due to very low germination percentages.

\section{Discussion}

Our study shows that aqueous smoke treatments improved germination of six out of the seven Mediterranean Lamiaceae taxa studied. Our results provide the first record of smoke-enhanced germination in four taxa endemic to the eastern Mediterranean Basin (Origanum onites, Teucrium lamiifolium ssp. stachyophyllum, Phlomis bourgaei and Stachys cretica ssp. smyrnaea). The records of germination stimulation by aqueous smoke in the latter two taxa are of additional importance since those taxa are regionally endemic to Turkey and the east Aegean islands, and especially when it is considered that the high-level dormancy (zero germination in the control) in S. cretica ssp. smyrnaea was broken by smoke solutions.

Aqueous smoke application resulted in faster germination in three taxa, besides the stimulation of germination. One of the outcomes of earlier germination of seeds is earlier emergence of seedlings. This is likely to have ecological consequences at the plant community level since early emergence of seedlings has a competitive advantage over the species with lateemergent seedlings (De Luis et al., 2008). In post-fire environments, similarly, early appearance of seedlings may give an advantage to a species to outcompete the others. The observed faster germination rate in aqueous smoke treatments in L. stoechas, S. thymbra and T. lamiifolium ssp. stachyophyllum, therefore, possibly contributes to the establishment success of these taxa after fire.

An increase in germination percentage and rate in aqueous smoke treatments has previously been observed in L. stoechas (Moreira et al., 2010, 2012), similar to the results of our study. However, two studies (Crosti et al., 2006; Çatav et al., 2012) failed to show an increase in germination percentage in this species, possibly because of loss of dormancy due to longer seed storage time (Çatav et al., 2012). Charred wood also stimulated germination in L. stoechas (Keeley and Baer-Keeley, 1999). Çatav et al. (2012) found an improvement in germination percentage in aqueous smoke treatment in a population of $S$. thymbra from around $100 \mathrm{~km}$ to the east of the seed collection area in the present study.

The importance of smoke in fire-induced germination in Mediterranean-type ecosystems of California (Keeley and Fotheringham, 1998), South Africa (Brown, 1993a) and Australia (Dixon et al., 1995) has long been known. However, it had been overlooked in the Mediterranean Basin, based on the presence of few records of smoke- or charred-wood-stimulated 
Table 4. List of the Lamiaceae species in which smoke-stimulated germination has been tested (including this study). The studies, conducted both with aqueous smoke solutions and with airborne smoke, are included in the table. GF is growth form and $\mathrm{R}$ is the germination response of the species to smoke

\begin{tabular}{|c|c|c|c|c|}
\hline Species & GF & Region & $\mathrm{R}$ & References \\
\hline \multicolumn{5}{|l|}{ Within Mediterranean-type ecosystems } \\
\hline Hemiandra pungens & $\mathrm{w}$ & Australia & 0 & Dixon et al., 1995 \\
\hline Hemiandra pungens & $\mathrm{w}$ & Australia & 0 & Roche et al., 1997 \\
\hline Lavandula latifolia & $\mathrm{w}$ & $\mathrm{MB}$ & + & Moreira et al., 2010 \\
\hline Lavandula stoechas & $\mathrm{w}$ & MB & 0 & Crosti et al., 2006 \\
\hline Lavandula stoechas & $\mathrm{w}$ & $\mathrm{MB}$ & + & Moreira et al., 2010 \\
\hline Lavandula stoechas & $\mathrm{w}$ & $\mathrm{MB}$ & + & Moreira et al., 2012 \\
\hline Lavandula stoechas & $\mathrm{w}$ & $\mathrm{MB}$ & 0 & Çatav et al., 2012 \\
\hline Lavandula stoechas & $\mathrm{w}$ & $\mathrm{MB}$ & + & The present study \\
\hline Origanum onites & $\mathrm{w}$ & $\mathrm{MB}$ & + & The present study \\
\hline Phlomis bourgaei & $\mathrm{w}$ & $\mathrm{MB}$ & + & The present study \\
\hline Prostanthera eurybioides & $\mathrm{w}$ & Australia & - & Ainsley et al., 2008 \\
\hline Rosmarinus officinalis & $\mathrm{w}$ & $\mathrm{MB}$ & + & Moreira et al., 2010 \\
\hline Rosmarinus officinalis & $\mathrm{w}$ & $\mathrm{MB}$ & 0 & Reyes and Trabaud, 2009 \\
\hline Salvia apiana & $\mathrm{w}$ & Cal & + & Keeley and Fotheringham, 1998 \\
\hline Salvia columbariae & a & Cal & + & Keeley and Fotheringham, 1998 \\
\hline Salvia leucophylla & $\mathrm{w}$ & Cal & + & Keeley and Fotheringham, 1998 \\
\hline Salvia mellifera & $\mathrm{w}$ & Cal & + & Keeley and Fotheringham, 1998 \\
\hline Satureja thymbra & $\mathrm{w}$ & $\mathrm{MB}$ & + & Çatav et al., 2012 \\
\hline Satureja thymbra & $\mathrm{w}$ & $\mathrm{MB}$ & + & The present study \\
\hline Sideritis angustifolia & $\mathrm{w}$ & MB & 0 & Moreira et al., 2010 \\
\hline Stachys cretica ssp. smyrnaea & $\mathrm{p}$ & $\mathrm{MB}$ & + & The present study \\
\hline Teucrium capitatum & w & $\mathrm{MB}$ & 0 & Moreira et al., 2010 \\
\hline Teucrium divaricatum ssp. divaricatum & $\mathrm{w}$ & MB & 0 & The present study \\
\hline Teucrium lamiifolium ssp. stachyophyllum & $\mathrm{p}$ & $\mathrm{MB}$ & + & The present study \\
\hline Teucrium ronniferi & w & $\mathrm{MB}$ & 0 & Moreira et al., 2010 \\
\hline Thymus piperella & $\mathrm{w}$ & MB & 0 & Moreira et al., 2010 \\
\hline Thymus vulgaris & $\mathrm{w}$ & $\mathrm{MB}$ & + & Moreira et al., 2010 \\
\hline \multicolumn{5}{|l|}{ Outside Mediterranean-type ecosystems } \\
\hline Ajuga australis & $\mathrm{p}$ & Australia & + & Clarke et al., 2000 \\
\hline Monarda citriodora & $\mathrm{a}$ & USA & 0 & Schwilk and Zavala, 2012 \\
\hline Monarda citriodora & $\mathrm{p}$ & USA & 0 & Chou et al., 2012 \\
\hline Monarda fistulosa & $\mathrm{p}$ & USA & 0 & Jefferson et al., 2008 \\
\hline Nepeta rtanjensis & $\mathrm{p}$ & Serbia & + & Todorović et al., 2007 \\
\hline Phlomis pungens & $\mathrm{p}$ & Turkey & 0 & Tavşanoğlu et al., in prep. \\
\hline Plectranthus parviflorus & $\mathrm{w}$ & Australia & + & Tang et al., 2003 \\
\hline Prostanthera askania & $\mathrm{w}$ & Australia & + & Tierney, 2006 \\
\hline Pycnanthemum pilosum & $\mathrm{p}$ & USA & + & Pennacchio et al., 2005 \\
\hline Pycnanthemum pilosum & $\mathrm{p}$ & USA & + & Ervin et al., 2010 \\
\hline Pycnanthemum pilosum & $\mathrm{p}$ & USA & 0 & Jefferson et al., 2008 \\
\hline Pycnanthemum virginianum & $\mathrm{p}$ & USA & + & Ervin et al., 2010 \\
\hline Salvia azurea & $\mathrm{p}$ & USA & - & Chou et al., 2012 \\
\hline Salvia coccinea & $\mathrm{p}$ & USA & + & Schwilk and Zavala, 2012 \\
\hline Salvia farinacea & $\mathrm{p}$ & USA & + & Schwilk and Zavala, 2012 \\
\hline Salvia iodantha & w & Mexico & - & Zuloaga-Aguilar et al., 2011 \\
\hline Salvia lavanduloides & $\mathrm{w}$ & Mexico & 0 & Zuloaga-Aguilar et al., 2011 \\
\hline Salvia penstemonoides & $\mathrm{p}$ & USA & 0 & Schwilk and Zavala, 2012 \\
\hline Salvia reflexa & a & USA & - & Chou et al., 2012 \\
\hline Salvia syriaca & $\mathrm{p}$ & Turkey & 0 & Tavşanoğlu et al., in prep. \\
\hline Salvia thyrsiflora & $\mathrm{w}$ & Mexico & - & Zuloaga-Aguilar et al., 2011 \\
\hline Stachys annua ssp. annua & $\mathrm{p}$ & Turkey & 0 & Tavşanoğlu et al., in prep. \\
\hline Stachys byzantina & $\mathrm{p}$ & Turkey & + & Tavşanoğlu et al., in prep. \\
\hline \multicolumn{5}{|l|}{ From unknown origin } \\
\hline Hemiandra sp. & $\mathrm{w}$ & Australia & + & Cochrane et al., 2002 \\
\hline Melissa officinalis & $\mathrm{p}$ & Iran? & 0 & Abdollahi et al., 2010 \\
\hline Microcorys eremophiloides & $\mathrm{w}$ & Australia & + & Cochrane et al., 2002 \\
\hline Salvia stenophylla & $\mathrm{w}$ & South Africa & + & Musarurwa et al., 2010 \\
\hline
\end{tabular}

a, Annual herb; $\mathrm{p}$, perennial herb; $\mathrm{w}$, woody; + , positive response; -, negative response; 0 , neutral response; MB, Mediterranean Basin; Cal, California, USA; USA, United States of America. 
germination in this region (Keeley, 1995; Keeley and Baer-Keeley, 1999; Buhk and Hensen, 2006), until more evidence was reported for Mediterranean Basin flora in recent years (Moreira et al., 2010; Çatav et al., 2012). Physiological seed dormancy (Baskin and Baskin, 2004; Karlsson and Milberg, 2008) and a waterpermeable seed coat (Moreira et al., 2010) are characteristics of the Lamiaceae family. Thus, the chemical compounds in smoke responsible for the stimulation of germination (such as karrikinolides) can pass the seed coat and break dormancy and/or improve germination in Lamiaceae species. Smokeenhanced germination in a number of Lamiaceae species was previously demonstrated in fire-prone environments of the Mediterranean Basin (Moreira et al., 2010) and California (Keeley and Fotheringham, 1998). Our results also support the hypothesis that germination in species of the Mediterranean Lamiaceae is improved by the existence of smoke chemicals. The Lamiaceae is one of the families in which a seeder mechanism is found in the Mediterranean Basin, as a result of phylogenetic clustering of fire-adapted traits (Verdú and Pausas, 2007). Fire-enhanced germination is one of these traits that allow Lamiaceae species to persist in frequently burned Mediterranean habitats. Indeed, 11 out of the 17 tested Lamiaceae species from Mediterranean ecosystems (including the present study) give a positive germination response to smoke (Table 4), while only five have no response and one has a negative response. On the other hand, studies performed with Lamiaceae species from outside the Mediterranean-type ecosystems showed a similar pattern $\left(\chi^{2}=2.1\right.$, df $\left.=2, P>0.05\right)$ with 9 positive, 7 neutral and 4 negative responses (Table 4). This suggests that smoke-enhanced germination in Lamiaceae is not restricted to Mediterranean-type ecosystems; however, more studies are needed to clarify this conclusion.

Lower concentrations of smoke solutions improved germination in T. lamiifolium ssp. stachyophyllum, $O$. onites and P. bourgaei, while the concentrated solution (1:1) had no effect on the germination percentage in these taxa. Conversely, S. cretica ssp. smyrnaea positively responded to the concentrated smoke solution but not to the 1:100 smoke solution treatment. This suggests the presence of a speciesspecific germination response to aqueous smoke solutions with different concentrations. This supports the suggestion of Keeley et al. (2012) that reporting a lack of smoke-stimulated germination is inconclusive 'without conducting an experiment over a large concentration gradient'.

In conclusion, our results contribute to the current limited knowledge on the smoke-enhanced germination in Mediterranean Lamiaceae, and support the idea that smoke is an important germination cue for this family.

\section{Acknowledgements}

The seeds were collected in the field with the permission of the Ministry of Food, Agriculture and Livestock of Republic of Turkey (no. 1379, dated 9 March 2012). The experiments were conducted in the laboratories of the Department of Biology, Muğla Sıtkı Koçman University, Turkey. We thank Costas A. Thanos and three anonymous reviewers for their comments, which helped improve the manuscript.

\section{Financial support}

The fieldwork of this study was supported by Hacettepe University Scientific Researches Unit (project no. 012.D06.601.0013).

\section{Conflicts of interest}

None.

\section{References}

Abdollahi, M., Aghavaisi, B., Asl, A.M. and Babolhavaeji, H. (2010) Comparative effects of plant-derived smoke and potassium nitrate on germination and post-germination parameters of four medicinal species. Planta Medica 76, P386, DOI: 10.1055/s-0030-1264684.

Adkins, S.W. and Peters, N.C.B. (2001) Smoke derived from burnt vegetation stimulates germination of arable weeds. Seed Science Research 11, 213-222.

Ainsley, P.J., Jones, M.K. and Erickson, T.E. (2008) Overcoming physiological dormancy in Prostanthera eurybioides (Lamiaceae), a nationally endangered Australian shrub species. Australian Journal of Botany 56, 214-219.

Baskin, J.M. and Baskin, C.C. (2004) A classification system for seed dormancy. Seed Science Research 14, 1-16.

Bond, W.J. and Keeley, J.E. (2005) Fire as a global 'herbivore': the ecology and evolution of flammable ecosystems. Trends in Ecology and Evolution 20, 387-394.

Brown, J.K. and Smith, J.K. (2000) Wildland fire in ecosystems: effects of fire on flora. General Technical Report RMRSGTR-42, Vol. 2. USDA Forest Service, Rocky Mountain Research Station, Ogden, Utah.

Brown, N.A.C. (1993a) Promotion of germination of fynbos seeds by plant-derived smoke. New Phytologist 123, 575-583.

Brown, N.A.C. (1993b) Seed germination in the fynbos fire ephemeral, Syncarpha vestita (L.) B. Nord. is promoted by smoke, aqueous extracts of smoke and charred wood derived from burning the ericoid-leaved shrub, Passerina vulgaris Thoday. International Journal of Wildland Fire 3, 203-206.

Brown, N.A.C. and Van Staden, J. (1997) Smoke as a germination cue: a review. Plant Growth Regulation 22, 115-124.

Buhk, C. and Hensen, I. (2006) 'Fire seeders' during early post-fire succession and their quantitative importance in 
south-eastern Spain. Journal of Arid Environments 66, 193-209.

Çatav, Ş.S., Bekar, İ., Ateş, B.S., Ergan, G., Oymak, F., Ülker, E.D. and Tavşanoğlu, Ç. (2012) Germination response of five eastern Mediterranean woody species to smoke solutions derived from various plants. Turkish Journal of Botany 36, 480-487.

Chou, Y.F., Cox, R.D. and Wester, D.B. (2012) Smoke water and heat shock influence germination of shortgrass prairie species. Rangeland Ecology and Management 65, 260-267.

Clarke, P., Davison, E.A. and Fulloon, L. (2000) Germination and dormancy of grassy woodland and forest species: effects of smoke, heat, darkness and cold. Australian Journal of Botany 48, 687-699.

Cochrane, A., Kelly, A., Brown, K. and Cunneen, S. (2002) Relationships between seed germination requirements and ecophysiological characteristics aid the recovery of threatened native plant species in western Australia. Ecological Management and Restoration 3, 47-60.

Crosti, R., Ladd, P.G., Dixon, K.W. and Piotto, B. (2006) Postfire germination: The effect of smoke on seeds of selected species from the central Mediterranean basin. Forest Ecology and Management 221, 306-312.

Davis, P.H. (Ed.) (1965-1985) Flora of Turkey and the East Aegean Islands, Vols 1-9. Edinburgh, Edinburgh University Press.

Daws, M.I., Davies, J., Pritchard, H.W., Brown, N.A.C. and Van Staden, J. (2007) Butenolide from plant-derived smoke enhances germination and seedling growth of arable weed species. Plant Growth Regulation 51, 73-82.

De Luis, M., Verdú, M. and Raventós, J. (2008) Early to rise makes a plant healthy, wealthy, and wise. Ecology 89, 3061-3071.

Dixon, K.W., Roche, S. and Pate, J.S. (1995) The promotive effect of smoke derived from burnt native vegetation on seed germination of Western Australian plants. Oecologia 101, 185-192.

Ervin S.L., Daugherty M., Coutant N.E. and Coons J.M. (2010) Influence of smoke solutions on the germination of twenty prairie plant species. Available from http:/ / www.eiu.edu/biology/posters/2010-04.pdf (accessed 7 May 2014).

Gürdal, B. and Kültür, Ş. (2013) An ethnobotanical study of medicinal plants in Marmaris (Muğla, Turkey). Journal of Ethnopharmacology 146, 113-126.

Herranz, J.M., Ferrandis, P. and Martínez-Sánchez, J.J. (1998) Influence of heat on seed germination of seven Mediterranean Leguminosae species. Plant Ecology 136, 95-103.

Jäger, A.K., Light, M.E. and Van Staden, J. (1996) Effects of source of plant material and temperature on the production of smoke extracts that promote germination of light-sensitive lettuce seeds. Environmental and Experimental Botany 36, 421-429.

Jefferson, L.V., Pennacchio, M., Havens, K., Forsberg, B., Sollenberger, D. and Ault, J. (2008) Ex situ germination responses of Midwestern USA prairie species to plantderived smoke. American Midland Naturalist 159, 251-256.

Karlsson, L.M. and Milberg, P. (2008) Variation within species and inter-species comparison of seed dormancy and germination of four annual Lamium species. Flora -
Morphology, Distribution, Functional Ecology of Plants 203, 409-420.

Kavgac1, A., Čarni, A., Başaran, S., Başaran, M.A., Košir, P., Marinšek, A. and Šilc, U. (2010) Long-term post-fire succession of Pinus brutia forest in the east Mediterranean. International Journal of Wildland Fire 19, 599-605.

Kazanis, D. and Arianoutsou, M. (2004) Long-term postfire vegetation dynamics in Pinus halepensis forests of Central Greece: A functional group approach. Plant Ecology 171, 101-121.

Keeley, J.E. (1995) Seed-germination patterns in fireprone Mediterranean-climate regions. pp. 239-273 in Arroyo, M.T.K.; Zedler, P.H.; Fox, M.D. (Eds) Ecology and biogeography of Mediterranean ecosystems in Chile, California and Australia. New York, SpringerVerlag.

Keeley, J.E. and Baer-Keeley, M. (1999) Role of charred wood, heat-shock, and light in germination of postfire phrygana species from the eastern Mediterranean basin. Israel Journal of Plant Sciences 47, 11-16.

Keeley, J.E. and Bond, W.J. (1997) Convergent seed germination in South African fynbos and Californian chaparral. Plant Ecology 133, 153-167.

Keeley, J.E. and Fotheringham, C.J. (1998) Smoke-induced seed germination in California chaparral. Ecology 79, 2320-2336.

Keeley, J.E. and Zedler, P.H. (1978) Reproduction of chaparral shrubs after fire: a comparison of sprouting and seeding strategies. American Midland Naturalist 99, $142-161$.

Keeley, J.E., Bond, W.J., Bradstock, R.A., Pausas, J.G. and Rundel, P.W. (2012) Fire in Mediterranean ecosystems: Ecology, evolution and management. Cambridge, Cambridge University Press.

Luna, B., Pérez, B., Torres, I. and Moreno, J.M. (2012) Effects of incubation temperature on seed germination of Mediterranean plants with different geographical distribution ranges. Folia Geobotanica 47, 17-27.

Moreira, B., Tormo, J., Estrelles, E. and Pausas, J.G. (2010) Disentangling the role of heat and smoke as germination cues in Mediterranean Basin flora. Annals of Botany 105, $627-635$.

Moreira, B., Tavsanoglu, Ç. and Pausas, J.G. (2012) Local versus regional intraspecific variability in regeneration traits. Oecologia 168, 671-677.

Musarurwa, H.T., Van Staden, J. and Makunga, N.P. (2010) In vitro seed germination and cultivation of the aromatic medicinal Salvia stenophylla (Burch. ex Benth.) provides an alternative source of $\alpha$-bisabolol. Plant Growth Regulation 61, 287-295.

Naghibi, F., Mosaddegh, M., Motamed, S.M. and Ghorbani, A. (2005) Labiatae family in folk medicine in Iran: from ethnobotany to pharmacology. Iranian Journal of Pharmaceutical Research 2, 63-79.

Paula, S., Arianoutsou, M., Kazanis, D., Tavsanoglu, Ç., Lloret, F., Buhk, C., Ojeda, F., Luna, B., Moreno, J.M., Rodrigo, A., Espelta, J.M., Palacio, S., FernándezSantos, B., Fernandes, P.M. and Pausas, J.G. (2009) Fire-related traits for plant species of the Mediterranean Basin. Ecology 90, 1420.

Pausas, J.G. and Verdú, M. (2005) Plant persistence traits in fire-prone ecosystems of the Mediterranean basin: a phylogenetic approach. Oikos 109, 196-202. 
Pennacchio, M., Jefferson, L.V. and Havens, K. (2005) Smoke: promoting germination of a tallgrass prairie species. Chicago Wilderness Journal 3, 14-19.

Pierce, S.M., Esler, K. and Cowling, R.M. (1995) Smokeinduced germination of succulents (Mesembryanthemaceae) from fire-prone and fire-free habitats in South Africa. Oecologia 102, 520-522.

Reyes, O. and Trabaud, L. (2009) Germination behaviour of 14 Mediterranean species in relation to fire factors: smoke and heat. Plant Ecology 202, 113-121.

Roche, S., Koch, J.M. and Dixon, K.W. (1997) Smoke enhanced seed germination for mine rehabilitation in the southwest of western Australia. Restoration Ecology 5, 191-203.

Schwilk, D.W. and Zavala, N. (2012) Germination response of grassland species to plant-derived smoke. Journal of Arid Environments 79, 111-115.

Simpson, M.G. (2010) Plant systematics. Amsterdam, Elsevier. Small, E. (2006) Culinary herbs. Canada, NRC Research Press.

Takhtajan, A. (2009) Flowering plants (2nd edition). Berlin, Springer-Verlag.

Tang, Y., Boulter, S.L. and Kitching, R.L. (2003) Heat and smoke effects on the germination of seeds from soil seed banks across forest edges between subtropical rainforest and eucalypt forest at Lamington National Park, south-eastern Queensland, Australia. Australian Journal of Botany 51, 227-237.

Tavşanoğlu, Ç. and Gürkan, B. (2014) Long-term postfire dynamics of co-occurring woody species in Pinus brutia forests: the role of regeneration mode. Plant Ecology 215, 355-365.

Tavşanoğlu, Ç., Çatav, Ş.S. and Özüdoğru, B. Fire in grasslands: Germination and early seedling growth in central Anatolian steppe (in prep.).
Thanos, C.A., Georghiou, K., Douma, D.J. and Marangaki, C.J. (1991) Photoinhibition of seed germination in Mediterranean maritime plants. Annals of Botany 68, 469-475.

Thanos, C.A., Georghiou, K., Kadis, C. and Pantazi, C. (1992) Cistaceae: A plant family with hard seeds. Israel Journal of Botany 41, 251-263.

Tierney, D.A. (2006) The effect of fire-related germination cues on the germination of a declining forest understorey species. Australian Journal of Botany 54, 297-303.

Todorović, S., Živković, S., Giba, Z., Grubišić, D. and Mišić, D. (2007) Basic seed germination characteristics of the endemic species Nepeta rtanjensis (Lamiaceae). Plant Species Biology 22, 205-210.

Tompsett, P.B. and Pritchard, H.W. (1998) The effect of chilling and moisture status on the germination, desiccation tolerance and longevity of Aesculus hippocastanum L. seed. Annals of Botany 82, 249-261.

Van Staden, J., Brown, N.A.C., Jäger, A.K. and Johnson, T.A. (2000) Smoke as a germination cue. Plant Species Biology 15, 167-178.

Verdú, M. and Pausas, J.G. (2007) Fire drives phylogenetic clustering in Mediterranean Basin woody plant communities. Journal of Ecology 95, 1316-1323.

Yeşilyurt, E.B. and Akaydın, G. (2012) Endemic plants and their threat categories of Muğla province (Turkey). Hacettepe Journal of Biology and Chemistry 40, 195-212.

Zuloaga-Aguilar, S., Briones, O. and Orozco-Segovia, A. (2011) Seed germination of montane forest species in response to ash, smoke and heat shock in Mexico. Acta Oecologica 37, 256-262. 